\title{
Working with argan cake: a new etiology for hypersensitivity pneumonitis
}

\author{
Christophe Paris ${ }^{1,2}$, Fabrice Herin ${ }^{3,4}$, Gabriel Reboux ${ }^{5,6}$, Emmanuelle Penven $^{1,2}$, Coralie Barrera ${ }^{5,6}$, Cécile Guidat ${ }^{7}$ \\ and Isabelle Thaon ${ }^{1,2^{*}}$
}

\begin{abstract}
Background: Argan is now used worldwide in numerous cosmetic products. Nine workers from a cosmetic factory were examined in our occupational medicine department, following the diagnosis of a case of hypersensitivity pneumonitis (HP) related to handling of argan cakes.

Methods: Operators were exposed to three forms of argan (crude granulates, powder or liquid) depending on the step of the process. All workers systematically completed standardized questionnaires on occupational and medical history, followed by medical investigations, comprising, in particular, physical examination and chest X-rays, total lgE and a systematic screening for specific serum antibodies directed against the usual microbial agents of domestic and farmer's HP and antigens derived from microbiological culture and extracts of various argan products. Subjects with episodes of flu-like syndrome several hours after handling argan cakes, were submitted to a one-hour challenge to argan cakes followed by physical examination, determination of Carbon Monoxide Diffusing Capacity (DLCO) and chest CT-scan on day 2, and, when necessary, bronchoalveolar lavage on day 4.
\end{abstract}

Results: Six of the nine workers experienced flu-like symptoms within 8 hours after argan handling. After challenge, two subjects presented a significant decrease of DLCO and alveolitis with mild lymphocytosis, and one presented ground glass opacities. These two patients and another patient presented significant arcs to both granulates and non-sterile powder. No reactivity was observed to sterile argan finished product, antigens derived from argan cultures (various species of Bacillus) and Streptomyces marokkonensis (reported in the literature to contaminate argan roots).

Conclusions: We report the first evidence of hypersensitivity pneumonitis related to argan powder in two patients. This implies preventive measures to reduce their exposure and clinical survey to diagnose early symptoms. As exposure routes are different and antibodies were observed against argan powder and not the sterile form, consumers using argan-based cosmetics should not be concerned.

Keywords: Hypersensitivity pneumonitis, Argan, Occupational diseases

\section{Background}

Argan is now used worldwide in numerous cosmetic products, as this fruit is supposed to possess many health properties related to its high unsaturated fatty acid and phytosterol content [1,2]. Argan oil is obtained according to an ancestral technique by heating, roasting and pressing the nuts contained in the fruit of Argania

\footnotetext{
* Correspondence: isabelle.thaon@univ-lorraine.fr

'Université de Lorraine, INGRES, EA 7298, Vandoeuvre lès Nancy F-54505, France

${ }^{2} \mathrm{CHU}$ Nancy, Centre de consultations de pathologies professionnelles, Vandoeuvre lès Nancy F-54511, France

Full list of author information is available at the end of the article
}

spinosa (Sapotaceae), an endemic tree growing in arid and semi-arid areas in South-West Morocco.

More recently, argan-derived products (proteins) extracted from argan cakes (residuals from pressing operations) have also been used in cosmetic products. To date, only one case of argan oil allergy has been reported in the literature, with digestive manifestations related to argan oil ingestion [3].

In January 2011, a 35 year-old man, a current smoker working in a cosmetic factory, was referred to the occupational medicine department of our university hospital. 
He reported brief episodes of flu-like syndrome (asthenia, myalgia, shivering, chest tightness) several hours after handling of crude argan powder derived from argan cakes. With his written and informed consent, the patient underwent a specific challenge to argan cake milling products at his workplace for one hour (D0), under medical supervision. This challenge was followed, eight hours later, by flu-like syndrome. Diffusing capacity of the lung for carbon monoxide (DLCO) decreased from 93\% predicted to $80 \%$ at D2 with no changes on HRCT scan. On D4, alveolitis $(602,000$ cells $/ \mathrm{mL})$ with discrete lymphocytosis (25\%), predominantly CD8 (60\%), was observed in bronchoalveolar lavage (BAL). Specific serum antibodies directed against antigens derived from extracts of various argan products were positive with up to seven arcs on electrosyneresis (ES). The diagnosis of Hypersensitivity Pneumonitis (HP) was established in this patient according to form 1 of the HP study classification [4].

Following this index case, presenting a new etiology for HP, we decided to conduct a systematic survey of all workers exposed under similar conditions in order to identify other possible cases of HP. A second objective was to identify the antigen responsible (microorganisms as in farmer's lung or protein as in pigeon breeders' lung [5]).

\section{Methods}

\section{Description of the industrial process}

Argan cakes (as granulates) arrive from Morocco in jute bags of $25 \mathrm{~kg}$ with no treatment after the pressing step. Argan cakes are initially delipidized by carbon dioxide at low temperature, and then milled to a fine powder. A second step of the process, including solubilization, filtration and sterilizing operations, results in a sterile finished product, in powder or liquid form. Operators are exposed to various levels of three forms of the product (granulates, powder and sterile powder) depending on the step of the process and protective measures. Workers wear filtration masks only during one step.

\section{Data collection}

All subjects were examined in our reference center after specific information on the examinations and after obtaining their written informed consent. All patients filled in a standardized questionnaire including personal use of argan products (in cosmetics or cooking), personal history of atopy, allergic rhinitis or asthma, smoking, flu-like symptoms (asthenia, myalgia, fever, chest tightness) after argan handling. Physical examination, anteroposterior chest X-ray and blood tests, including total IgE, were performed in the absence of any recent argan exposure. After specific treatment and extraction of proteins from argan products (see below), a specific identification of precipitins in workers' sera was systematically performed.
All subjects with episodes of flu-like syndrome several hours after handling argan cakes, underwent the same workplace specific challenge test to argan powder as that performed in the index case. The challenge test was organized in the workplace with the collaboration of the factory occupational physician and a resident of our center, under the usual conditions of the industrial process. On D2, the workers underwent physical examination with blood count, of pulmonary function tests by plethysmography (Vmax - Autobox V62J Encore, SensorMedics, Yorba Linda, CA), and chest HRCT scan. On D4, BAL was proposed only in subjects with flu-like symptoms during the hours following argan exposure and association of significant features on either HRCT scan (ground-glass opacities) or pulmonary function tests (more than 10\% decrease DLCO after challenge).

\section{Culture and antigen extracts}

The three forms of argan were processed by one of the authors (GR) to extract microorganisms and specific antigens. The methods have been previously published [6,7]. Endotoxin assay was also performed by the National Institute of Safety Research (INRS) [8]. Culture and isolations methods are described in Additional file 1.

Three total crude extracts were prepared by extraction from crude sample materials according to the form: granulates, powder and sterilized finished product. This technique is adapted from Pépys et al. [9] (see Additional file 1). Two somatic antigens (Bacillus Licheniformis and Bacillus sp.) were derived from bacteria isolated from "argan" (powder and granulates). Antigens were prepared as previously described [7] (see Additional file 1).

As a review of the literature showed that argan roots are commonly contaminated by Streptomyces marokkonensis [10], S. marokkonensis antigen was prepared from the original strain (DMZ 41918) isolated from the Argania spinosa tree.

For ELISA technique, special protein form of antigens was made using a recombinant $\beta$-1,3-glucanase and proteins were pelleted with trichloroacetic acid [11] (see Additional file 1).

\section{Serology techniques}

All sera were tested by two techniques using the same batches of antigen. Serum precipitins were investigated by agar gel Ouchterlony double diffusion (DD) [12] and electrosyneresis (ES) on cellulose acetate [13]. All results were read blindly by two operators and no difference was observed between the two readings. Serological techniques have been previously described in detail in supplementary data on Journal of Medical Microbiology [6]. Moreover an ELISA IgG technique (Enzyme-Linked ImmunoSorbent Assays) was also used for all sera. Technique was described previously by Roussel et al. [11]. 


\section{Results}

Nine subjects, one female and eight male, including the case index, were included in the study. Their main characteristics are reported in Table 1. Six subjects, including the index case, reported similar respiratory symptoms: flu like symptoms early in the evening following argan handling. Physical examination and initial chest X-rays in the absence of any recent exposure to argan were normal in all patients (Table 2). Table 2 also presents the results of specific challenge tests.

In the index case (\#1), the challenge reproduced the symptoms within 8 hours, but physical examination remained normal. HRCT scan did not demonstrate any significant abnormalities. BAL revealed the presence of alveolitis with 602,000 cells $/ \mathrm{mL}$ and discrete $(25 \%)$ but significant lymphocytosis in this smoker $[14,15]$ with a predominance of CD8 (60\%). Noteworthy, the DLCO was decreased to $78 \%$ predicted.

Three of the five new symptomatic patients (\#2, \#5 and \#9) did not present any alteration of DLCO or HRCT scan after specific challenge. In subject \#3, a current smoker, who presented an abnormal DLCO before and after the challenge (63\% and $61 \%$ predicted, respectively), HRCT scan demonstrated the presence of centrilobular emphysema. BAL was at the limit of normal. The last subject (\#4), also a current smoker, presented a significant decrease of DLCO after the challenge (62\% predicted vs $88 \%$ predicted), and localized ground-glass opacities on HRCT scan on D2 after challenge. However, BAL failed to demonstrate the presence of lymphocytosis in this case (18\%). As this stage, the diagnosis of HP was only suspected in this subject.

\section{Microbiological results}

Only two Bacillus species were identified in all aqueous samples: Bacillus licheniformis and Bacillus spp. $200 \mathrm{CFU/g}$ and $400 \mathrm{CFU} / \mathrm{g}$ of $\mathrm{B}$. licheniformis in granulated and "argan" powder, respectively. Bacillus spp. was isolated at a concentration of $400 \mathrm{CFU} / \mathrm{g}$ and $2000 \mathrm{CFU} / \mathrm{g}$ in the same samples. In a second sample of argan cake, 3 strains of Bacillus were identified by DNAr $16 \mathrm{~S}$ sequence and phenotypic characteristics (B. pumilus, B. clausii, B. subtilis). No other bacteria, actinomycetes or fungi were isolated.

\section{Serology results}

The two patients (\#1 and \#4) with suspected HP after the specific challenge presented significant arcs to both granulates and non-sterile powder (seven and three arcs with ES technique in case \#1 and five and three arcs in case \#4, respectively, see Table 3). Patient \#9, who reported flu-like symptoms after argan handling but with no change in DLCO or HRCT scan after specific challenge, also presented significant arcs to both granulates and non-sterile powder (four and three arcs with ES technique, respectively). These three patients also had elevated IgG against argan granulates and/or argan powder (Table 4).

No reactivity was observed against antigens derived from bacteria (Bacillus spp. including B. pumilus, B. clausii,

Table 1 General and occupational characteristics of the subjects sample

\begin{tabular}{|c|c|c|c|c|c|c|c|c|c|}
\hline Cases & $\begin{array}{l}\text { Gender } \\
\text { (age) }\end{array}$ & $\begin{array}{l}\text { Tobacco } \\
\text { status }\end{array}$ & $\begin{array}{l}\text { Domestic argan } \\
\text { exposure }\end{array}$ & Workstation & $\begin{array}{l}\text { First exposure } \\
\text { to argan }\end{array}$ & $\begin{array}{l}\text { Frequency of } \\
\text { exposure to } \\
\text { argan granule }\end{array}$ & $\begin{array}{l}\text { Last exposure } \\
\text { to argan }\end{array}$ & $\begin{array}{l}\text { Complaints } \\
\text { suggestive } \\
\text { of HP }\end{array}$ & $\begin{array}{l}\text { Onset and duration } \\
\text { of complaints } \\
\text { suggestive of HP }\end{array}$ \\
\hline 1 & Male (35) & $\mathrm{s}$ & No & $\begin{array}{l}\text { production } \\
\text { operator }\end{array}$ & 2006 & monthly & $\begin{array}{l}\text { previous } \\
\text { month }\end{array}$ & $\begin{array}{l}\text { flu-like } \\
\text { syndrome }\end{array}$ & $\begin{array}{l}\text { Early evening and for } \\
\text { several hours }\end{array}$ \\
\hline 2 & Male (28) & FS & No & $\begin{array}{l}\text { production } \\
\text { operator }\end{array}$ & 2008 & monthly & $\begin{array}{l}\text { previous } \\
\text { month }\end{array}$ & $\begin{array}{l}\text { flu-like } \\
\text { syndrome }\end{array}$ & $\begin{array}{l}\text { Early evening and for } \\
\text { several hours }\end{array}$ \\
\hline 3 & Male (35) & FS & No & $\begin{array}{l}\text { production } \\
\text { operator }\end{array}$ & 2007 & monthly & $\begin{array}{l}\text { previous } \\
\text { month }\end{array}$ & $\begin{array}{l}\text { flu-like } \\
\text { syndrome }\end{array}$ & $\begin{array}{l}\text { Early evening and for } \\
\text { several hours }\end{array}$ \\
\hline 4 & Male (39) & FS & No & $\begin{array}{l}\text { production } \\
\text { (foreman) }\end{array}$ & 2007 & monthly & $\begin{array}{l}\text { previous } \\
\text { month }\end{array}$ & $\begin{array}{l}\text { flu-like } \\
\text { syndrome }\end{array}$ & $\begin{array}{l}\text { Early evening and for } \\
\text { several hours }\end{array}$ \\
\hline 5 & Male (30) & S & No & $\begin{array}{l}\text { production } \\
\text { operator }\end{array}$ & 2007 & occasionally & $\begin{array}{l}\text { previous } \\
\text { month }\end{array}$ & No & / \\
\hline 6 & Male (35) & S & No & $\begin{array}{l}\text { production } \\
\text { operator }\end{array}$ & 2007 & monthly & $\begin{array}{l}\text { previous } \\
\text { month }\end{array}$ & No & / \\
\hline 7 & Male (45) & S & No & $\begin{array}{l}\text { "powder" } \\
\text { workshop }\end{array}$ & 2006 & occasionally & $\begin{array}{l}\text { previous } \\
\text { month }\end{array}$ & No & / \\
\hline 8 & $\begin{array}{l}\text { Female } \\
\text { (40) }\end{array}$ & NS & No & packaging & 2007 & monthly & $\begin{array}{l}\text { previous } \\
\text { month }\end{array}$ & No & / \\
\hline 9 & Male (34) & NS & No & $\begin{array}{l}\text { production } \\
\text { operator }\end{array}$ & 2006 & occasionally & $\begin{array}{l}\text { previous } \\
\text { month }\end{array}$ & $\begin{array}{l}\text { flu-like } \\
\text { syndrome }\end{array}$ & $\begin{array}{l}\text { Early evening and for } \\
\text { several hours }\end{array}$ \\
\hline
\end{tabular}


Table 2 Summary of investigations for the diagnosis of Hypersensitivity pneumonitis

\begin{tabular}{|c|c|c|c|c|c|c|c|c|}
\hline \multicolumn{4}{|c|}{ Before specific challenge } & \multicolumn{5}{|c|}{ After specific challenge * } \\
\hline Cases & $\begin{array}{l}\text { Physical } \\
\text { examination }\end{array}$ & $\begin{array}{l}\text { Chest } X \\
\text { rays }\end{array}$ & $\overline{\mathrm{DLCO}}$ & $\begin{array}{l}\text { Symptoms } \\
\text { suggestive of HP }\end{array}$ & $\begin{array}{l}\text { DLCO (variation) \% } \\
\text { predicted }^{\dagger}\end{array}$ & $\mathrm{CT} \mathrm{Scan}^{\dagger}$ & $\mathrm{BAL}^{\ddagger}$ & Conclusion \\
\hline 1 & normal & normal & $89 \%$ & Yes & $78 \%(-11 \%)$ & No specific abnormalities & $\begin{array}{l}600000 / \mathrm{mL} 25.5 \% \\
\text { lymphocytes }\end{array}$ & $\mathrm{HP}$ \\
\hline 2 & normal & normal & $118 \%$ & Yes & $120 \%$ & / & / & ODTS \\
\hline 3 & normal & normal & $63 \%$ & Yes & $61 \%$ & Emphysema & $\begin{array}{l}935000 / \mathrm{mL} 5 \% \\
\text { lymphocytes }\end{array}$ & ODTS \\
\hline 4 & normal & normal & $88 \%$ & Yes & $62 \%(-22 \%)$ & $\begin{array}{l}\text { Localized Ground-glass } \\
\text { opacities }\end{array}$ & $\begin{array}{l}600000 / \mathrm{mL} 18 \% \\
\text { lymphocytes } \\
\text { (not available) }\end{array}$ & $\mathrm{HP}$ \\
\hline 5 & normal & normal & $68 \%$ & Yes & $79 \%$ & / & / & ODTS \\
\hline 6 & normal & normal & $85 \%$ & / & / & / & / & / \\
\hline 7 & normal & normal & $79 \%$ & / & / & / & / & / \\
\hline 8 & normal & normal & $86 \%$ & / & / & / & / & / \\
\hline 9 & normal & normal & $95 \%$ & Yes & $94 \%$ & / & / & ODTS \\
\hline
\end{tabular}

* one-hour challenge (D0) to argan cakes at the workplace, only performed in the 6 subjects with flu-like symptoms in the 8 hours following argan handling. + at day 2 after challenge.

${ }^{\ddagger}$ at day 4 after challenge-, only performed in subjects with significant features either on HRCT scan (ground-glass opacities) or pulmonary function tests (more than $10 \%$ decrease of DLCO after challenge).

/: not performed.

HP: Hypersensitivity Pneumonitis, ODTS: Organic Dust Toxic Syndrome.

B. subtilis, B. licheniformis and S. marokkonensis) in any of the subjects. Noteworthy, none of the subjects presented arcs against the sterile argan finished product. No arcs were identified in a serum pool of 9 urban adults without exposure to farm products or birds. None of subjects presented any exposure to other common risk of HP.

Finally, on the basis of the presence of clinical symptoms after exposure, ground-glass opacities on HRCT scan and positive serology, the diagnosis of HP was adopted for case \#4 as well as case \#1.

\section{Discussion}

Two cases of documented HP related to handling argan cake were identified among nine exposed workers in a factory using argan cake. Positive diagnosis was based on the presence of the following criteria after specific challenge test at the workplace: presence of suggestive

Table 3 Number of precipitin arcs for four antigens in workers exposed to argan and non-exposed controls

\begin{tabular}{|c|c|c|c|c|c|c|c|c|c|c|}
\hline \multirow[t]{3}{*}{ Case } & \multicolumn{10}{|c|}{ Precipitin arcs $n$} \\
\hline & \multicolumn{2}{|c|}{ Argan granulates } & \multicolumn{2}{|c|}{ Argan powder } & \multicolumn{2}{|c|}{ Sterile finished product } & \multicolumn{2}{|c|}{ Bacillus spp } & \multicolumn{2}{|c|}{ Streptomyces marokkonensis } \\
\hline & $\overline{\mathrm{ES}^{*}}$ & $\mathrm{DD}^{\dagger}$ & ES & DD & $\overline{E S}$ & DD & ES & DD & ES & DD \\
\hline \multicolumn{11}{|c|}{ Workers exposed to Argan } \\
\hline 1 & 7 & 4 & 3 & 4 & 1 & 1 & 0 & 1 & 0 & 0 \\
\hline 2 & 2 & 0 & 0 & 2 & 0 & 0 & 0 & 0 & 1 & 0 \\
\hline 3 & 2 & 1 & 1 & 1 & 0 & 0 & 0 & 2 & 0 & 0 \\
\hline 4 & 5 & 2 & 3 & 2 & 0 & 0 & 0 & 1 & 1 & 0 \\
\hline 5 & 2 & 1 & 1 & 1 & 0 & 0 & 0 & 1 & 1 & 0 \\
\hline 6 & 2 & 1 & 1 & 1 & 0 & 0 & 0 & 0 & 1 & 0 \\
\hline 7 & 2 & 1 & 1 & 1 & 0 & 0 & 0 & 1 & 0 & 0 \\
\hline 8 & 2 & 1 & 1 & 1 & 0 & 0 & 0 & 0 & 1 & 0 \\
\hline 9 & 4 & 3 & 3 & 1 & 0 & 0 & 0 & 0 & 0 & 0 \\
\hline \multicolumn{11}{|c|}{ Non exposed Controls } \\
\hline 1 (serum pool $\left.\right|^{\ddagger}$ ) & 1 & 0 & 0 & 2 & 0 & 0 & 0 & 0 & 0 & 0 \\
\hline
\end{tabular}

*ES = electrosyneresis.

${ }^{\dagger}$ double diffusion.

${ }^{\ddagger}$ from 9 other urban adults without exposure to farm products or birds. 
Table 4 Mean IgG and total IgE in workers exposed to argan and exposed controls

\begin{tabular}{|c|c|c|c|c|c|c|}
\hline \multirow[t]{2}{*}{ Case } & \multirow[t]{2}{*}{ Total lgE (IU/ml) } & \multicolumn{4}{|l|}{ Average IgG } & \multirow[b]{2}{*}{$\begin{array}{l}\text { Streptomyces. } \\
\text { marokkonensis Ag }\end{array}$} \\
\hline & & $\begin{array}{l}\text { Argan granule } \\
\text { Ag (ARG Ag) }\end{array}$ & $\begin{array}{l}\text { Argan powder } \\
\text { Ag (ARP Ag) }\end{array}$ & $\begin{array}{l}\text { Argantensyl } \\
\text { Ag (ART Ag) }\end{array}$ & Bacillus spp. Ag & \\
\hline \multicolumn{7}{|c|}{ Workers exposed to Argan } \\
\hline 1 & 80 & 2.48 & 2.37 & 3.25 & 0.13 & 0.10 \\
\hline 2 & 559 & 1.10 & 1.00 & 0.55 & 0.12 & 0.13 \\
\hline 3 & 261 & 1.17 & 0.94 & 0.22 & 0.10 & 0.29 \\
\hline 4 & 144 & 0.96 & 1.48 & 1.48 & 0.10 & 0.14 \\
\hline 5 & 100 & 1.30 & 1.03 & 0.27 & 0.10 & 0.19 \\
\hline 6 & 47 & 1.52 & 0.92 & 0.45 & 0.11 & 0.09 \\
\hline 7 & 21 & 0.14 & 0.22 & 0.14 & 0.13 & 0.09 \\
\hline 8 & 65 & 0.51 & 0.56 & 0.28 & 0.10 & 0.10 \\
\hline 9 & 112 & 1.49 & 1.25 & 1.12 & 0.13 & 0.09 \\
\hline \multicolumn{7}{|c|}{ Non exposed controls } \\
\hline 1 (serum pool*) & / & 0.45 & 0.62 & 0.22 & 0.14 & 0.11 \\
\hline
\end{tabular}

*from 9 other urban adults without exposure to farm products or birds.

clinical symptoms within 8 hours, significant specific serum antibodies to extracts or argan granulates and non-sterile powder (Precipitins and IgG), significant decrease of DLCO, presence of ground glass opacities (only in subject \#4), presence of alveolitis (in both) subjects with mild lymphocytosis (25\% in subject \#1). Four other patients with suggestive clinical symptoms occurring after argan handling but with no HRCT scan or DLCO changes were considered to present organic dust toxic syndrome, as a significant level of endotoxins (4200 EU/g) was observed in argan cake granulates. Finally, one of these patients presented a lobular emphysema on HRCT scan with altered DLCO, not modified by challenge to argan, and associated with active smoking.

The accuracy of the diagnosis of HP needs to be discussed. In the case index, the combination of symptoms, mild lymphocytosis on BAL, significant decrease of DLCO after challenge with complete recovery in the absence of exposure and the presence of specific serum antibodies with argan granulates or non-sterile powder, appeared to be sufficient to confirm the diagnosis of HP. In absence of lymphocytosis in the second case, the diagnosis of HP may be more doubtful. However, the presence of slight ground-glass opacities on HRCT scan, a significant decrease of DLCO after specific challenge, with recovery in the absence of exposure, as well as significant arcs to antigens derived from argan cake, were clearly in favor of the diagnosis. Moreover, all clinical features were mild and totally reversible after removal from occupational exposure, which could also explain the absence of respiratory crackles on physical examination, as also reported in $32 \%$ of patients with form one of the HP study. The positive diagnosis of HP is fairly complex [5] and several classifications have been proposed in the literature [4,16-18]. In most classifications, the major criterion is a combination of suggestive clinical symptoms after exposure to antigens, HRCT abnormalities, specific serum antibodies and lymphocytosis on BAL. However, a decrease in DLCO, positive challenge or inspiratory crackles are considered to be major or minor criteria depending on the classification, and these classifications remain controversial. In particular, a recent study observed that HRCT abnormalities were strongly associated with chronic forms of the disease, but may be absent in more acute forms. Accordingly, we assume that our two patients presented an acute form of HP (or active as proposed by Lacasse et al. in the HP study) [4]. Interestingly, the very low frequency of exposure (less than one hour every month for some workers) may explain the paucity and the transient nature of clinical features. The intensity of exposure and repeated exposure are known risk factors for HP [19-21]. The cases described here demonstrate that HP can also occur in very particular circumstances associated with infrequent exposure.

The marked differences between specific serum antibodies against non-sterile forms of argan (both granulate and powder) and sterile forms first suggest that a microbial agent may be responsible for the disease. However, cultures for the microorganisms usually involved in HP were negative, as were specific antibodies for these agents despite the use of several specific media. A review of the literature also found that argan roots are commonly contaminated by Streptomyces marokkonensis [10]. As some other Streptomyces spp. are known to be responsible for $\mathrm{HP}$, this may constitute an interesting hypothesis to explain our findings. Unfortunately, all specific serological tests derived from the Streptomyces marokkonensis extract remained negative in all subjects. The last explanation, 
under the hypothesis of causative microbial agent, is that this agent is a no viable or uncultivable bacteria or fungi. However, these negative results and the fact that, to the best of our knowledge, HP has never been previously described in the literature among workers (mainly women) of argan cooperatives, also suggest that the antigen responsible could be a protein. In this case, differences observed between specific serum antibodies against argan granulates and powder and against the sterile form could be explained by a heat-labile protein. Further investigations are required to identify the protein or microbial agent responsible for the HP observed in these two patients.

\section{Conclusions}

We report two cases of acute HP associated with argan powder manipulation before sterilization. No similar cases have been previously reported. Moreover, our findings also highlight the fact that HP can occur even in a context of infrequent exposure.

\section{Ethics}

In this case series report, all the procedure are clinically indicated and confirmed by a pluridisciplicinary medical staff (multidisciplanarystaff for occupational allergic disease of the university hospital of Nancy). All cases agreed that theirs results could be published.

\section{Additional file}

Additional file 1: Culture and antigen extract.

\section{Abbreviations}

BAL: Bronchoalveolar lavage; CO: Carbon monoxide; CD4: Cluster of differentiation 4; CD8: Cluster of differentiation 8; D0: Day zero (day of specific challenge); D2: Day two (following specific challenge); D4: Day four (following specific challenge); DD: Ouchterlony double diffusion; DLCO: Carbon Monoxide Diffusing Capacity; ELISA: Enzyme-Linked ImmunoSorbent Assays; ES: Electrosyneresis on cellulose acetate; HRCT: High-resolution computed tomography; HP: Hypersensitivity pneumonitis; ODTS: Organic Dust Toxic Syndrome.

\section{Competing interests}

The authors declare that they have no competing interests.

\section{Authors' contributions}

CP contributed to the study design; data acquisition, their analysis, and their interpretation; drafting and revision of the manuscript and is the guarantor of the content of the manuscript including the data and analysis. FH, contributed to the study design; data acquisition, analysis, and interpretation and revision of the manuscript GR contributed to study design, acquisition, analysis, and interpretation of data related to microbiological analysis, culture and antigen extracts, and serology, and revision of the manuscript. EP, contributed to the study design; data acquisition, analysis, and interpretation and revision of the manuscript. CB, contributed to acquisition, analysis, and interpretation of data related to microbiological analysis, culture and antigen extracts, and serology and revision of the manuscript. CG, contributed to clinical data acquisition in particular and organization of challenge and revision of the manuscript. IT contributed to the study design; interpretation of data; drafting and revision of the manuscript. All authors read and approved the final manuscript.

\section{Acknowledgements}

We thank Cecile Poussel who contributed to acquisition of the data. The authors received only funding from their employers. CP, EP and IT: Université de Lorraine and Centre Hospitalier Universitaire (CHU) de Nancy. FH: Université de Toulouse and CHU de Toulouse. GR: Université de Franche Comté and CHU de Besançon. CB: Université de Franche Comté. CG: Association Lorraine de Santé en Milieu de Travail (association of occupational physicians of Lorraine).

The manuscript preparation has been made using only annual funding from research unit INGRES (EA7298) of the Université de Lorraine.

\section{Author details}

${ }^{1}$ Université de Lorraine, INGRES, EA 7298, Vandoeuvre lès Nancy F-54505, France. ${ }^{2} \mathrm{CHU}$ Nancy, Centre de consultations de pathologies professionnelles, Vandoeuvre lès Nancy F-54511, France. ${ }^{3} \mathrm{CHU}$ Toulouse, Service des Maladies Professionnelles et Environnementales, Toulouse F-31000, France. ${ }^{4}$ Université de Toulouse, UMR 1027, Toulouse F-31000, France. ${ }^{5}$ UMR/CNRS 6249 Chrono Environnement, Université de Franche-Comté, Besançon F-25030, France. ${ }^{6}$ Service de Parasitologie-Mycologie, CHU J. Minjoz, Besançon F-25030, France. ${ }^{7}$ Association Lorraine de Santé en Milieu de Travail, Pulnoy F-54425, France.

Received: 16 June 2014 Accepted: 19 February 2015

Published online: 06 March 2015

\section{References}

1. Khallouki F, Younos C, Soulimani R, Oster T, Charrouf Z, Spiegelhalder B, et al. Consumption of argan oil (Morocco) with its unique profile of fatty acids, tocopherols, squalene, sterols and phenolic compounds should confer valuable cancer chemopreventive effects. Eur J Cancer Prev. 2003;12(1):67-75.

2. Derouiche A, Cherki M, Drissi A, Bamou Y, El Messal M, Idrissi-Oudghiri A, et al. Nutritional intervention study with argan oil in man: effects on lipids and apolipoproteins. Annals Nutrition Metabolism. 2005;49(3):196-201.

3. Astier C, Benchad Yel A, Moneret-Vautrin DA, Bihain BE, Kanny G. Anaphylaxis to argan oil. Allergy. 2010;65(5):662-3.

4. Lacasse Y, Selman M, Costabel U, Dalphin JC, Morell F, Erkinjuntti-Pekkanen R, et al. Classification of hypersensitivity pneumonitis: a hypothesis. Int Arch Allergy Immunol. 2009;149(2):161-6.

5. Lacasse $Y$, Girard M, Cormier Y. Recent advances in hypersensitivity pneumonitis. Chest. 2012;142(1):208-17.

6. Reboux G, Piarroux R, Roussel S, Millon L, Bardonnet K, Dalphin JC. Assessment of four serological techniques in the immunological diagnosis of farmers' lung disease. J Med Microbiol. 2007;56(Pt 10):1317-21.

7. Reboux G, Piarroux R, Mauny F, Madroszyk A, Millon L, Bardonnet K, et al. Role of molds in farmer's lung disease in Eastern France. Am J Respir Crit Care Med. 2001;163(7):1534-9.

8. Greff-Mirguet G. Echantillonage et analyse des endotoxines dans l'air. Cahier de Notes Doc Hygiène et Sécurité du Travail. 2002;187:73-87.

9. Pepys J, Jenkins PA, Festenstein GN, Gregory PH, Lacey ME, Skinner FA. Farmer's lung: thermophilic actinomycetes as a source of "farmer's lung hay" antigen. Lancet. 1963;2(7308):607-11.

10. Bouizgarne B, Lanoot B, Loqman S, Sproer C, Klenk HP, Swings J, et al. Streptomyces marokkonensis sp. nov., isolated from rhizosphere soil of Argania spinosa L. Int J Syst Evol Microbiol. 2009;59(Pt 11):2857-63.

11. Roussel S, Reboux G, Rognon B, Monod M, Grenouillet F, Quadroni M, et al. Comparison of three antigenic extracts of Eurotium amstelodami in serological diagnosis of farmer's lung disease. Clin Vaccine Immunol CVI. 2010;17(1):160-7.

12. Ouchterlony O. Antigen-antibody reactions in gels. IV. Types of reactions in coordinated systems of diffusion. Acta Pathologica et Microbiologica Scandinavica. 1953;32(2):230-40.

13. Gari M, Smets P, Pinon JM, Recco P, Sequela JP. Use of immuno-electrodiffusion on cellulose acetate for the research of the precipitating antibodies in the screening of patients suspected of farmer's lung disease. Mycopathologia. 1982;78(3):151-3.

14. The BAL Cooperative Group Steering Committee. Bronchoalveolar lavage constituents in healthy individuals, idiopathic pulmonary fibrosis, and selected comparison groups. Am Rev Respir Dis. 1990;141 (5 Pt 2):S169-202.

15. Semenzato G, Bjermer L, Costabel U, Haslam PL, Olivieri D. Clinical guidelines and indications for bronchoalveolar lavage (BAL): extrinsic allergic alveolitis. Eur Respir J. 1990;3(8):945-6. 961-969. 
16. Richerson HB, Bernstein IL, Fink JN, Hunninghake GW, Novey HS, Reed CE, et al. Guidelines for the clinical evaluation of hypersensitivity pneumonitis. Report of the Subcommittee on Hypersensitivity Pneumonitis. J Allergy Clin Immunol. 1989;84(5 Pt 2):839-44.

17. Schuyler $M$, Cormier $Y$. The diagnosis of hypersensitivity pneumonitis. Chest. 1997;111(3):534-6.

18. Lacasse Y, Selman M, Costabel U, Dalphin JC, Ando M, Morell F, et al. Clinical diagnosis of hypersensitivity pneumonitis. Am J Respir Crit Care Med. 2003;168(8):952-8.

19. Dalphin JC, Pernet D, Reboux G, Martinez J, Dubiez A, Barale T, et al. Influence of mode of storage and drying of fodder on thermophilic actinomycete aerocontamination in dairy farms of the Doubs region of France. Thorax. 1991;46(9):619-23.

20. Malmberg P, Rask-Andersen A, Rosenhall L. Exposure to microorganisms associated with allergic alveolitis and febrile reactions to mold dust in farmers. Chest. 1993;103(4):1202-9.

21. Rodriguez de Castro F, Carrillo T, Castillo R, Blanco C, Diaz F, Cuevas M. Relationships between characteristics of exposure to pigeon antigens. Clinical manifestations and humoral immune response. Chest. 1993;103(4):1059-63.

\section{Submit your next manuscript to BioMed Central and take full advantage of:}

- Convenient online submission

- Thorough peer review

- No space constraints or color figure charges

- Immediate publication on acceptance

- Inclusion in PubMed, CAS, Scopus and Google Scholar

- Research which is freely available for redistribution 